\title{
LIMITS AND RISK OF DEVELOPING TRANSPORT INFRASTRUCTURE IN POLAND
}

\begin{abstract}
Low investment and other mistakes made in the process of transport development has led to the situation where even the infrastructure of the most developed transport branches does not correspond to European standards. Underdevelopment of transport infrastructure in Poland has become one of the main barriers to growth and modernization of the country. Well-developed transport infrastructure is an important determinant of socio-economic development.

Over 25 years after the start of the economic transformation in Poland, the condition of transport infrastructure in this country remains unsatisfactory. However, since the accession to the European Union, the development of transport infrastructure in Poland has improved significantly. Funds from the EU have contributed significantly to this progress.

The current financial perspective may be the last chance for Poland to get EU funding for transport infrastructure development in such a large scale. Therefore, it is particularly important that the allocated funds are fully absorbed. For this to happen, project beneficiaries should be able to obtain funds for their own contributions. The increase in bond yields related to rating downgrade, weakening banks or shifting funds from investment to consumption may weaken Poland's ability to take advantage of opportunities arising from EU funds.
\end{abstract}

(C) Stanisław Miecznikowski, 2017.

Miecznikowski Stanisław, Professor, University of Gdańsk, Poland. 


\section{Key words:}

Investment, transport, infrastructure, bonds, finance, reform, regional, risks, budget.

JEL: R4, R40, R5.

\section{Introduction}

For many decades, the development and technical condition of the transport infrastructure in Poland has been assessed as insufficient. Low investment and other mistakes made in the process of transport development has led to the situation where even the infrastructure of the most developed transport branches does not correspond to European standards. Underdevelopment of transport infrastructure in Poland has become one of the main barriers to growth and modernization of the country. Well-developed transport infrastructure is an important determinant of socio-economic development. Transport infrastructure represents complementary capital which creates the conditions for the functioning of private production and service companies. Good transport accessibility is, inter alia, one of the location factors of foreign direct investment, which create new jobs, innovation and income (Musiał-Malago, 2014, p. 36; Myna, 2010, p. 45).

Improvement of transport accessibility of individual voivodships, especially areas which are important for the competitiveness of regions (ports and economic centres, recreation areas) is among the main directions and priorities in the development of transport infrastructure in Poland. In development of transport infrastructure special emphasis is placed on the construction of motorways and expressways and high-speed railway lines in international transport corridors, construction of efficient road connections to ports and logistics centres in areas of particular importance, the development of air transport, including the modernization of airports, the expansion of ports and ferry bases, modernization of international inland waterways, modernization of access roads to major centres, modernization of regional railways and entry into service of light railway rolling stock, infrastructural and organizational integration of regional passenger transport. Another very important aspect in the development of transport infra- 
structure is to improve road safety and reduce transport's nuisance and harmful effects on the environment (Salmonoiwcz, 2011, pp. 4983-4984).

Poland's accession to the European Union (EU) on 1 May 2004 has given a chance for this country for fast rehabilitation of transport infrastructure and improvement of its quality standards due to the increased funding opportunities. The aim of the study is to present the financing of transport infrastructure in Poland, both before and after the Poland's accession to the European Union. Particular attention is paid to the current political and economic situation in Poland which may constitute a threat to the process of further rapid development of transport infrastructure in the country.

\section{Financing the transport infrastructure before entering the EU}

Since 1991, the most important challenges before successive Poland's governments had been the economic transition and gaining membership in the EU. The country had to prepare for a successful participation in the EU cohesion policy after accession. An important step towards this was the administrativeterritorial reform which was adopted in 1998 and went into effect in 1999. The reform introduced a three-level administrative division. Poland has been divided into 16 voivodeships (provinces) which replaced the 49 former voivodeships. Each voivodeship is subdivided into powiats (named also counties or districts), which are further divided into gminas (municipalities or communes). Since the accession to the EU, each Poland's voivodships has been a region of the EU corresponding to the EU NUTS II level.

The 1999 administrative-territorial reform created a clearer regional dimension of government (Copsey, 2013, p. 205). The new territorial entities have been granted wide competencies including the responsibility for delivering regional development policy (Dąbrowski, 2007; Regional policy in Poland, 2011). Regional self-governments have been entitled to independently set development strategies and plans, as well as programmes and projects aimed at their implementation at the voivodeship level (Regional policy in Poland, 2011; Mapa pomocy Unii Europejskiej udzielonej Polsce w ramach programu Phare 19902003). Therefore, the conditions for reliable development project planning and implementation have been improved.

The 1999 administrative-territorial reform was made in anticipation of substantial EU funding for development at the regional level (Copsey, 2013, p. 205). However, until the EU accession on May 1, 2014, Poland had been receiving only the EU pre-accession assistance under the three funds: PHARE, ISPA and SAPARD. It is estimated that in 1990-2003, the overall EU support for Poland 
exceeded EUR 7 billion (Mapa pomocy Unii Europejskiej udzielonej Polsce w ramach programu Phare 1990-2003, 2003; Salmonoiwcz, 2011). Over the same period, under PHARE and ISPA, Poland received about EUR 1.9 billion for transport development. The EU pre-accession assistance was very small compared to post-accession funding. Nevertheless, it had played an important role in preparing candidate countries for the appropriate EU structural funds (Rolbiecki, 2010, pp. 28-31).

Considering the above, at the local government units level, the possibilities of funding transport infrastructure projects from external sources were very limited. In addition to the contribution from the EU, sources of external financing included funds from the multilateral institutions such as the European Bank for Reconstruction and Development or the European Investment Bank. However, these funds were of minor importance. Some municipalities issued bonds to fund transport infrastructure projects. An example of this may be the issue of municipal bonds by Gdynia in 1996 to purchase several dozen low-suspension buses (Miecznikowski and Turek, 2005).

The bonds allowed gminas to acquire capital competitively. They enabled long term investments to be financed efficiently and effectively. Ventures which were undertaken as a result of bond issues tended to stimulate future economies of cities. Owing to municipal bonds, local government bodies could obtain their own shares in investments, which might in turn give them a chance to raise funds from the European Union within the framework of programmes such as PHARE and ISPA.

Moreover, at the same time, bonds became a means of active engagement for the local communities. They enabled them to gain new and attractive investors. Owing to issuance of municipal bonds, local communities had an opportunity to make investors, funds and banks aware of them as trustworthy and innovative partners.

Nevertheless, until the accession to the EU in May 2004, the state budget had been the main source of funding transport infrastructure projects in Poland (Musiat-Malago, 2005, p. 58). The main reason for this was the centralisation of power in the hand of Polish government. However, as the central government the state budget had been the main source of funding transport infrastructure projects budget was not in equilibrium, there were small opportunities to allocate large sums of money for financing transport infrastructure. 


\section{Financing the transport infrastructure after accession to the EU}

With the accession to the EU, Poland has been entitled to apply for EU funds. EU funding opportunities for Poland improved substantially with the beginning of the new EU financial perspective 2007-2013. Under this financial framework, Poland was allocated 67.3 billion EUR (compared to EUR 12.8 billion in 2004-2006), which made that country the biggest beneficiary of EU funds (European Funds Portal).

Spending on transport has the largest share in the structure of EU financial support for Poland. In 2004-2013, transport projects accounted for $36 \%$ of total value of all project financing agreements, ranging from $25 \%$ in the KuyavianPomeranian Voivodeship to approximately $45 \%$ in the Łódź Voivodeship (Ministerstwo Infrastruktury i Rozwoju, 2014, p. 20).

From 2004 to 2013, EUR 28.7 billion of EU funds went to transport infrastructure projects in Poland. In 2007-2013, $673 \mathrm{~km}$ of motorways were built, and $808 \mathrm{~km}$ of expressways were built or modernised, worth a total of EUR 16 billion, of which EUR 10 billion was EU co-funding (Ministry of Foreign Affairs, 2014; Miecznikowski, 2015). In 2007-2013, more than EUR 5 billion of EU funds were allocated for railway investments. They should result in modernization or revitalization of over $2,600 \mathrm{~km}$ of tracks (Ministerstwo Rozwoju Infrastruktury). It is worth noting that investments in road transport have surpassed railway investments.

It should be added that four TEN-T (Trans-European Transport Networks) corridors cross Poland. There are two north-south and two east-west corridors. The first north-south corridor links Helsinki to Gdansk via Tallinn, Riga, KaunasKlaipeda and Warsaw. The other one leads from Gdansk to Katowice and Źilina, it has also a western branch Katowice-Brno. One on the east-west corridors connects Berlin to Nizhny Novgorod via Poznan, Warsaw, Brest, Minsk, Smolensk and Moscow. The second one is from Brussels to Aachen, Cologne, Dresden, Wroclaw, Katowice, Cracow, Lviv and Kiev. Under the financial framework 20072013 the main emphasis was placed on the north-south corridors.

An example of the use of EU funds at the regional level is the construction of the Pomeranian Metropolitan Railway (PMR) line which will finally link Tri-City to Lech Wałęsa Airport and the Kashubian region. The PMR provides a great opportunity for the region in terms of labour market development, attracting new projects from business services sector or the residential and commercial real estate segment [15]. The project will also contribute to the environmental protection and tourism development. 
In the case of the Pomerania region, investment in railways surpasses investment in road infrastructure. This trend continues. The situation is different than in the country as a whole.

In the programming period 2014-2020, Poland should receive EUR 82.5 billion (Tri-City Pomeranian Metropolitan Railway opened). As in the previous financial framework, the largest amounts are to be invested in transport infrastructure. However, currently, the European Commission places greater emphasis on railway investment, because rail is much ecological than road transport. The Commission has increased funding for rail infrastructure for passenger transport. In particular, the Commission considers the development of high speed rail (HSR) as a priority within the trans-European networks. Among others, the European Commission plans to finance the high speed rail of «via Baltica» which would link Estonia to Poland via Lithuania and Latvia. The cost of its construction is to be EUR 4.5 billion (Miecznikowski, 2015).

As of January 31, 2016, under the programming period 2014-2020, the General Directorate of National Roads and Motorways (Generalna Dyrekcja Dróg Krajowych i Autostrad - GDDKiA) submitted payment applications which relate to 13 projects for constructing expressways including such sections as Kaźmierzów Legnica, Nowa Sól Południowa - Kaźmierzów or Olsztyn - Olsztynek. Total EU co-funding for these projects are estimated at over PLN 8 billion (approximately EUR 2 billion). On the other hand, railways are still falling behind on investment. By the end of January 2016 , contracted works amounted to only $7 \%$ of total value of all railway investment projects planned for implementation under the 20142020 EU financial framework [GDDKiA liczy na 2 mld z Brukseli, 2016].

\section{Current risks for financing infrastructure in Poland}

On January 15, 2016, Standard \& Poor's Ratings Services (S\&P), which is one of the Big Three credit-rating agencies, lowered the long-term foreign currency sovereign credit rating on Poland from «A-» to «BBB+». In support of that decision, S\&P stated that new Poland's government led by Law and Justice party, which in the election in October 2015 won an absolute majority in the parliament and the senate, has initiated various legislative measures that weaken the independence and effectiveness of key institutions, such as the constitutional court and public broadcasting. S\&P also changed the Poland's rating outlook to negative fearing that there is potential for further erosion of the independence, credibility, and effectiveness of key institutions, especially the National Bank of Poland. The Agency also expressed concern that - contrary to earlier expectations - Poland's fiscal metrics would not improve and some reversals in the country's sound macroeconomic management of the past years would be ob- 
served. Several days after the S\&P announcement, Moody's Investors Service another credit-rating agency from the «Big Three»- raised Poland's deficit forecast for 2016 and warned that larger than expected deficits and changes to expenditure rule made by Polish authorities are credit negative (Thomson Reuters).

Also, the third main credit-rating agency, Fitch, warned Poland against the danger of downgrade. It confirmed that deficits much above $3 \%$ of GDP would be rating-negative. The agency warned that it could cut Poland's rating, if the country's decision to convert Swiss franc-denominated mortgages significantly undermined the health of the banking sector (Thomson Reuters). It should be added that Poland's authorities adopted earlier the law which imposes tax on assets of financial institutions. Since February 1, 2016, banks in Poland have been charged $0.44 \%$ of their adjusted total assets annually. According to Moody's estimates, the tax will cost the Poland's banking sector EUR 1 billion in 2016, which is equivalent to one third of banks' annual earnings for the first ten months of 2015/16 (Moody's: Poland's bank tax threatens credit ratings).

\section{Figure 1}

\section{Poland's public budget deficit as a percentage of GDP*}

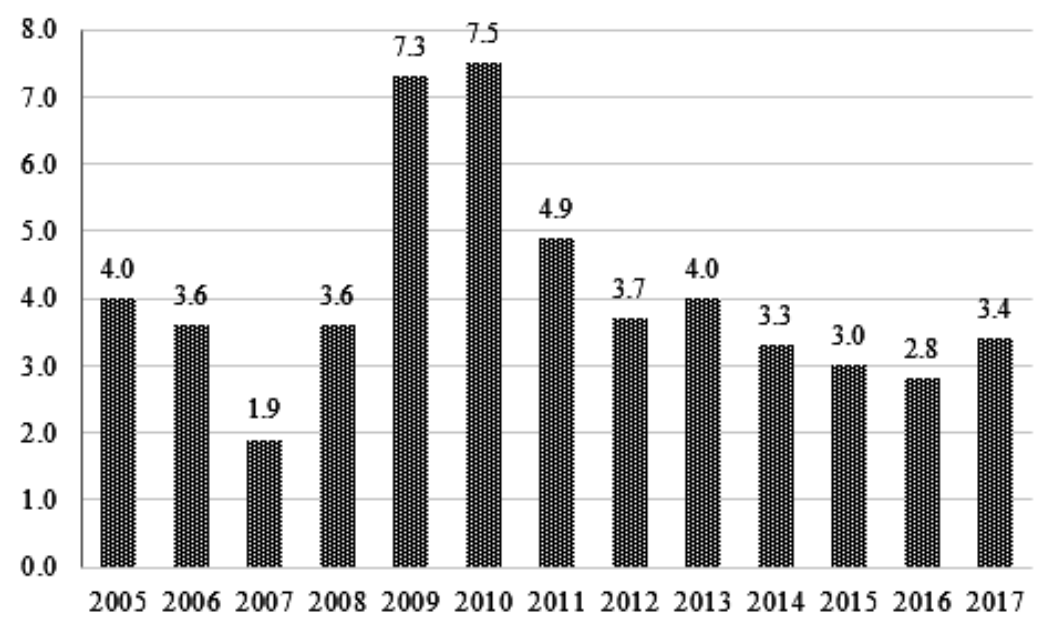

* For 2015-2017 - forecast of the European Commission as of 4 February 2016.

Source: (European Commission). 
As can be seen, the all three main credit-rating agencies emphasise the risks of higher government budget deficit in Poland. As shown in Figure 1, the country's public budget deficit peaked during the global financial and economic crisis to 7.3\% of GDP in 2009 and 7.5\% of GDP in 2010. However, in 20112015, except for 2013, the deficit followed a downward trend and decreased to about $3 \%$ in 2015. In June 2015, the Council of the European Union closed the excessive deficit procedure for Poland which had been subject to that procedure since July 2009. According to forecast of the European Commission from the beginning of February 2016, Poland's public budget deficit will fall to $2.8 \%$ of GDP in 2016 and then will rise to $3.4 \%$ of GDP in 2017 . However, relatively low public budget deficit in 2016 will partly arise from the exceptional revenues from the auction of LTE frequencies (PLN 9 billion or $0.5 \%$ of GDP) which will are not likely to be repeated in the following years (Thomson Reuters). Additionally, a very expensive flagship project of «PLN 500 per child per month» was launched in April 2016 and will not cover the whole year.

It should be noted that the S\&P's rating downgrade for Poland is the first such change in the country's history. Developments of the long-term foreign currency sovereign credit rating on Poland are presented in the Table 1.

Table 1

Developments of the long-term foreign currency sovereign credit rating on Poland

\begin{tabular}{|c|c|c|c|c|c|}
\hline \multicolumn{2}{|c|}{ S\&P } & \multicolumn{2}{c|}{ Moody's } & \multicolumn{2}{c|}{ Fitch } \\
\hline BBB+ & $\begin{array}{c}15-J a n-2016 \\
\text { (latest change) }\end{array}$ & A2 & $\begin{array}{c}12-N o v-2002 \\
\text { (latest change) }\end{array}$ & A- & $\begin{array}{c}18-J a n-2007 \\
\text { (latest change) }\end{array}$ \\
\hline A- & 29-Mar-2007 & Baa1 & 14-Jan-2002 & BBB+ & 19-Nov-1998 \\
\hline BBB+ & $15-M a y-2000$ & & & & \\
\hline BBB & $10-J u n-1999$ & & & & \\
\hline BBB- & $10-$ Apr-1996 & & & & \\
\hline BB & $01-J u n-1995$ & & & & \\
\hline
\end{tabular}

Source: [18].

The S\&P downgrade has led to the increase in the yield on Poland's bonds. On the next working day after the S\&P announcement, the yield on Poland's 10-year bonds rose 22 basis points, the most since September 2014. There was the selloff in the longer-dated securities which pushed their premium over two-year notes to the widest since at least 2002 (Onoszko and Krasuski). In 
the public finance sector debt management strategy in the years 2015-2018, Poland's stipulates that the average maturity of domestic debt will be increased to about 4.5 years (Ministry of Finance, 2014, p. 5). However, a growing reluctance of investors to hold money in Poland's longer-dated bonds may make this goal difficult to achieve (Onoszko and Krasuski).

It should be noted that issuance of long-term bonds is a source of financing or co-financing of transport infrastructure investment (Fundacja FOR et al, Którędy droga?, 2009, p. 42). The EU co-funding usually reaches about threequarters of total project costs, the rest is own contribution. However, after signing a project agreement, a beneficiary must cover all costs with its own funds. EU funding is released after project completion. An increase in bond yields would have a negative impact on investment costs. Moreover, actions leading to the weakening of the banking sector may limit its ability to provide financing to the Polish economy including capital-intensive transport infrastructure investment. On the other hand, it is likely that banks will pass partly the new tax onto borrowers, which would also adversely affect the cost of financing of infrastructure investment.

Efforts by new Poland's government to fulfil election promises may lead not only to higher government budget deficit but also to the increase in consumption at the expense of investment spending.

\section{Conclusions}

Over 25 years after the start of the economic transformation in Poland, the condition of transport infrastructure in this country remains unsatisfactory. However, since the accession to the European Union, the development of transport infrastructure in Poland has improved significantly. Funds from the EU have contributed significantly to this progress.

The current financial perspective may be the last chance for Poland to get EU funding for transport infrastructure development in such a large scale. Therefore, it is particularly important that the allocated funds are fully absorbed. For this to happen, project beneficiaries should be able to obtain funds for their own contributions. The increase in bond yields related to rating downgrade, weakening banks or shifting funds from investment to consumption may weaken Poland's ability to take advantage of opportunities arising from EU funds. 


\section{References}

1. Musiał-Malago M., Zróżnicowanie dostępności transportowej województw Polski, Zeszyty Naukowe, nr 4 (928), Uniwersytet Ekonomiczny w Krakowie, Kraków 2014.

2. Myna A. Uwarunkowania i skutki niedorozwoju ponadregionalnej infrastruktury transportowej na przykładzie woj. lubelskiego, «Barometr Regionalny» 2010, Nr 2 (20).

3. Salmonoiwcz K., Źródła finansowania rozwoju infrastruktury transportu wodnego śródlądowego w Polsce, «Logistyka» 2011, nr 6.

4. Copsey N., Poland: An Awkward Partner Redeemed, in: The Member States of the European Union, eds. S. Bulmer, C. Lequesne, Oxford University Press, London 2013.

5. Dabrowski M., Implementing Structural Funds in Poland: Institutional Change and Participation of the Civil Society, "Political Perspectives Graduate Journal» 2007, Vol. 5, Issue 2.

6. Regional policy in Poland, Ministry of Regional Development, Warsaw 2011.

7. Mapa pomocy Unii Europejskiej udzielonej Polsce w ramach programu Phare 1990-2003, ISPA 2000-2003 oraz SAPARD, Urząd Komitetu Integracji Europejskiej, Warszawa 2004.

8. Rolbiecki R., Wykorzystanie funduszy unijnych w branży transportowej w Polsce, «Logistyka» 2010, nr 1.

9. Miecznikowski S., Turek M., Municipal bonds as an instrument for financial local rolling stock in Poland, in: Railway stock of 21 century: ideas, needs and projects, Petersburg State Transport University, Sankt-Petersburg 2005.

10. Musiał-Malago M., Transport and infrastructure in Poland: the current state and projects for the future, «European Transport» 2005, no 30.

11. European Funds Portal, http://www.funduszestrukturalne.gov.pl [access: 30.01.2016].

12. Wpływ członkostwa Polski w Unii Europejskiej i realizowanej polityki spójności na rozwój kraju, Ministerstwo Infrastruktury i Rozwoju, Warszawa 2014.

13. 2014 Poland's 10 years in the European Union, Ministry of Foreign Affairs, Warszawa 2014.

14. Sektor Kolejowy w Polsce. The railway sector in Poland, Ministerstwo Rozwoju Infrastruktury, http://www.funduszestrukturalne.gov.pl [access: 30.01.2016]. 
15. Tri-City Pomeranian Metropolitan Railway opened, http://www.jll.pl [access: 30.01.2016].

16. Miecznikowski S., Problemy zastosowania kompleksowej analizy kosztów i korzyści linii kolei dużych prędkości a ich konkurencyjność na europejskim pasażerskim kolejowym rynku transportowym, Zeszyty Naukowe Wydziału Ekonomicznego Uniwersytetu Gdańskiego, Nr 57, Wydawnictwo Uniwersytetu Gdańskiego, Gdańsk 2015.

17. GDDKiA liczy na 2 mld z Brukseli, «Puls Biznesu», 29-31.01.2016.

18. Thomson Reuters, data from Thomson Reuters Eikon on the basis of the cooperation agreement between the University of Gdansk and Thomson Reuters [access: 29.01.2016].

19. Moody's: Poland's bank tax threatens credit ratings, http://www.ft.com [access: 29.01.2016].

20. European Commission, http://ec.europa.eu/ [access: 02.03.2016].

21. Onoszko M., Krasuski K., Poland Feels Sting From Downgrade as LongTerm Debt Costs Soar, http://www.bloomberg.com [access: 29.01.2016].

22. The public finance sector debt management strategy in the years 2015-2018, Ministry of Finance, Warsaw, September 2014.

23. Fundacja FOR et al, Którędy droga?, Raport o tym, jak odblokować inwestycje drogowe w Polsce, Warszawa 2009. 